] $\mathrm{F} \rightleftharpoons$ International Journal of Technical Research \& Science

\title{
AN ANALYSIS UNTO THE VALIDATION OF MARKET SEGMENTATION FROM THE INDIAN VYAPARI'S PERSPECTIVE
}

\author{
Bijit Sinha \\ E-Mail Id: hydranzia@gmail.com \\ Department of English, Faculty of Arts, University of Delhi, Delhi, India
}

\begin{abstract}
With complete access to international trade, India is completely able to adjust to the new trends and ensure good packaging and efficient transportation in the case of handicraft industries. To change the bracket of international trade, India has recently attempted to emphasize upon the local trade to focus upon the small-scale handicraft markets and bring it up to the level of the international markets, as can be seen in international platforms such as IHGF. But one recurrent problem that has always been noticed in the Indian exports is the lack of a proper methodological way of presenting the right product to the right markets. In the heyday of the trade products, where even the other countries can manage to sell the same ethnic products such as saris, one must consider if the lot of innovative ideas for better sales is merely relegated to show off new fusion and ethnic designs, to add to the appeal of the exotic and the oriental. The focus of this paper is to look toward alternative and cost-cutting ways through which the small-time traders could achieve relative progress, such as better packaging of their fragile products, and utilizing the ethnic factor to suit the contemporary tastes, such as effecting religious images unto technological devices, etc. With a detailed analysis unto the ways of international market segmentation, the paper will verify if such modifications in accordance to various cultural contexts is beneficial in the long run, and if so, to what extent would the compromise on part of the generational vyapari would occur in terms of the rising bulk demands in the Middle East and the Western regions.
\end{abstract}

Keywords: Indian International Trade, Indian vyapari, market segmentation, ethnicity, cultural demand.

\section{INTRODUCTION}

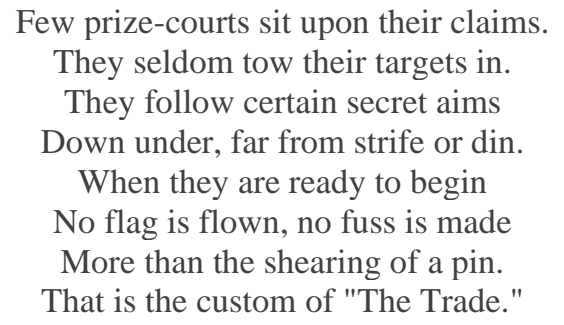

The Trade by Rudyard Kipling

The Indian handicraft industry presently stands out as one of the major key suppliers of handicraft goods in the international market. It should be noted that most of the artisans engage in the oft generational craft on a part-time basis. As the present trend of the commoditization of handicrafts production has been furthered in shorter product lifecycles, the industry has seemingly grown in terms of luxury items and its online presence. Over the past decade, the handicraft exports have greatly contributed to the summative exports of the country. The handicraft exports from India increased by 13.5 per cent during the period of April-September 2016 to US\$ 1.9 billion, regarding the ethnic metal-ware, woodcrafts, hand printed textiles and imitation jewellery. But it can be noticed that the Indian handicrafts industry is significantly fragmented, even though seven million regional artisans and more than 67,000 export houses are actively promoting the dying art of regional craftsmanship upon international trade fairs such as IHGF. If we look at the handicraft product more closely, we might notice that the exotic element of the product stems from the time-consuming process of handicraft production. Rather than historically tracing the recurrent problems of the Indian cottage industries, the paper furtively seeks to tackle the tussle between change and authenticity which has been alienating the artisan from his hand-crafted craft, with the wide implementation of machine made goods. Though it draws out the all-common troupe of the conflict between man and machine, it will take up an alternative view upon the same, by taking up the vyapari and the shilpi as two separate parties with distinct motives of their own, respectively. While the paper would attempt to specifically focus into the movement of traditional and small-scale produced goods by the Indian artisans, it would also employ a more humanistic framework to usher in the degree of adaptability that occurs within the artisanal clusters at present, and how exactly, can one weave a possible synthesis to the given conundrum. But even still, there has been a stagnancy since there is 


\section{J}

a varying lack between the number of demands and the deficient supply to match up to it. Following intermittently through the quotients of technological support and the degrees of innovation that have been applied to this industry in this recent years, this paper shall also try to validate the claim whether it is truly effecting the economic growth of the artisanal clusters. (Ghouse 1185)

\section{RESEARCH ELABORATION}

The recent surge in the Indian export of handicrafts due to recent trends in the cultural valuation of the ethnic souvenir that is highly valued by the international buyer, serves as the primary facets in the movement in the handicraft international trade. If one looks at the bigger picture, India easily stands out as the market boasting of an abundance of domestic cheap labor that closely matches up to that of China with an intricate craftsmanship that is unique. But the fact that the industry itself is not well structured and falls short of skilled labour due to lower literacy levels and a major lack of awareness programs about the present trends in fashion couture and home décor, is evidentially tantamount to the lack of proper infrastructural facilities in the same even though it presents a steady growth over the years. While this falls short of the parameters stated by the $12^{\text {th }}$ Five Year plan in India, one ought to keep in mind that the plan has not failed. In fact, lack of enough credit, lesser access of raw material was directly tackled by the $12^{\text {th }}$ Five Year plan in India. The $12^{\text {th }}$ Five Year Plan (2012-2017) envisions the handicraft sector to "create globally competitive handicrafts and provide sustainable livelihood opportunities to the artisans through innovative product designs, better product quality use and use of technology while preserving traditional art." (Jadhav 10) While there has been an overall mediation by the government toward the preservation of dying traditional art forms, not much can be said about the artisan. Now, when we come to the artisan and his/her form of art, it would be better highlighted by UNESCO's delineation of the same. "'Artisanal products are those produced by artisans, either completely by hand, or with the help of hand tools or even by mechanical means, as long as the direct manual contribution of the artisan remains the most substantial component of the finished product. The special nature of the finished products derives from their distinctive features, which can be utilitarian, aesthetic, creative, culturally attached, decorative, functional, traditional, religiously and socially symbolic and significant."

\section{FINDINGS}

With the exponential growth of the e-commerce sectors in India, handicraft exporters have been joining hands with these major portals to tap into the domestic market. With the rising demand of handicraft products from the Indian market as well as the upsurge of Indian e-commerce platforms such as Flipkart and Snapdeal, the annual exports of the handicraft goods ranges between $3 \$$ to $4 \$$ billion. But since the handicraft industry is a cottage based, labour intensive sector, even though the e-commerce platforms have been accelerating the growth of the handicraft industries at an international level, the recurrent problems remain unsolved. Even though the industry has been taken under the wing of $\mathrm{EPCH}$, the solution seemingly remains at bay. The Export Promotion Council for Handicrafts $(\mathrm{EPCH})$ is the apex government body and operates under the administrative control of the Ministry of Textiles, Government of India. EPCH has since long been considered a model council that self-finances all of its promotional activities. Their projected growth of the total export of handicrafts from India was expected to grow by $10 \%$, i.e. US\$ 3.5 billion in the fiscal year 2016-2017. (Exports Promotion Council for Handicrafts)

The following snippets from EPCH's Mega Panel Discussion held on $22^{\text {nd }} F e b$ ', 2016, would serve to shed a better light on the prevalent deficits in the Indian handicraft industries.

Mr. Vikram Chitnis, the business head of the home division of Shoppers Stop, comments upon the fact that even with a steady growth of e-commerce sectors in India over the past three years, Indian products have been gaining more and more credibility in the international market, though it has fallen short in terms of variation and utility.

Ms. Sonali Bhandari, the Senior Buying Manager at Westside, notes that even though there has been momentous growth in the domestic markets accredited to the rising rate of foreign buyers, there has been a latent hesitation within the ranks of the domestic buyers.

Summing it up, the biased perception of the domestic buyers, the supposed limited variation of the Indian craft (implying a limited niche market as its target), can be stated as some of the recurrent deficiencies regarding the Indian handicraft industry. One of the factors which have been listed as one of the primary consequences is in fact, lack of quality packaging.

The major recurrent complaint in overseas trade has been the fact that Indian handicrafts do not usually come with quality packaging. With an apparent difference between what the customer demands and what he receives, the vyapari must ensure that these issues are solved through prompt implementation of feedback loops or a one-to-one correspondence with the buyer. With the merging of the entrepreneurship faculties and the artisanal communities, there are emerging possibilities of organized retail businesses that might just ensure the appropriate margins to supply the goods which are placed against order in bulk. In between the varying purchasing power of each market, the vyapari must take note of the purchasing power of the country he exports his goods to. For example, by 


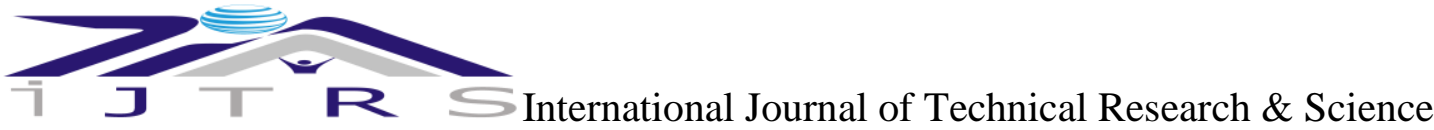

considering the high purchasing economies, such as Russia and Kazakhstan, if s/he is not able to deliver it in bulk, then the worth of the buyer is lost in the process. In other instances, consisting of mid and lower purchasing markets, such as Azerbaijan, Armenia, and Kyrgyztan, the vyapari must reorient his marketing strategies, to analyze the age bracket and appropriate the products respectively. Furthermore, s/he should merge modern trends according to the demands of a new product and couple it with a relevant form of ethnicity, so as to cater to the demands of the cosmopolitan buyer. The Chinese cottage industries excel in this aspect, as seen in their merging of low sale products such as a common mousepad, and transforming it into a Feng-shui gift item, thus entering a niche market altogether and cutting excessive costs in the process. The vyapari ought to relate the product and modify it to suit the needs of the market for a personalized approach. This may percolate down to purely utilitarian uses, such as accupressure pointed chappals which would be highly interest the international buyer if it is presented as a healing product.

With the transition from the purchasing of outsourced high-end brands to that of the root source, i.e, the handcrafted items which earlier seemed much outdated, the buyer tends to think of it as a more natural and authentic trade without the corporate forces at work. But in truth, not much has changed within this parameter. Now, when we come to the quotient of authenticity, it can be said that the buyer's decision is dependent upon the negotiation between the authenticity and his/her expectations and incentives to buy handicrafts. While this presupposes the myth of change equating lower levels of authenticity, a closer look unto the tradition-tied artisan's want of recognition/izzat, suggests that educating the present market demands with the artisan's goods tagged along with an underlying hope of the survival of the trade, might just amount to a meager solution as of now. This has been evidenced by Baba Saheb Ambedkar Hastshilp Vikas Yojana (AHVY), which has successfully promoted upgradation of artisanal skill as well as basic infrastructural facilities within its own artisanal clusters and cooperative communities.

\section{CONCLUSION}

When the artisan was previously thought to be making products of superior quality, the very assumption that s/he is now well accounted for the work he has done is a sham. (Hanwell 1) There is a lack of transparency within the production and distribution levels and it is visibly apparent in the present economic state. And when the buyer is introduced to the equation, it can be seen that the cosmopolitan buyer intends to know more about the artisan and products when they buy any handmade products. While it may signify a subtle integration of the foreign buyer to the tradition of the artisan cluster, it cannot be denied that this purports the exclusive demand of elite crafts by the elite buyer. As this results in a concoction of stories that relate to the background of the craft's production, it sets up the notion that the buyer's social status is in fact, validated. This can be backed by Weber's definition of status which is in direct correlation to a progressive measurement of social class, degree of respect, and social value of the individual. Thus, the craft supposedly gains its credibility in terms of desirability and rarity; the primary conceptions which suit the buyer's tastes. And even though the buyer remains oblivious throughout all of it, a wide implementation of a thorough procedure of the buyer being involved in the craft-making process, through established processes of craft routes that include on-sight training for the artisan as well as providing a unique shopping experience for the buyer signifying a cross sector cohesion, would serve to attain a new highlight in the tourism manual, which would be further exemplified by the Somaiya Kala Vidya institution focusing on a localized mode of learning of block printing and patchwork for both the artisan and the foreign buyer. Thus, the community in formation would be eventually appreciating the trade for what it's worth.

\section{APPENDIX}

\section{$>$ Shilpi- Artisan \\ REFERENCES}

[1] Ghouse, Suhail M., Indian handicraft Industry: Problems and Strategies, International Journal of Management Research and Review, Volume 2, Issue 7, Article no. 8, July 2012. Web.

[2] Exports Promotion Council for Handicrafts, Indian Handicrafts Industry and Exports, www.ibef.org, http://www.ibef.org/exports/handicrafts-industry-india.aspx, November 2016. Web.

[3] Jadhav, Shreya, Indian Handicrafts: Growing or Depleting?, IOSR Journal of Business and Management (IOSR-JBM), http://www.iosrjournals.org/iosr-jbm/papers/ies-mcrc-volume-2/15.pdf, Web.

[4] Hanwell, Matthew, Artisan OD- A New Tribe for the HR World? , Change, Human Resources, OD, Organization, https://theillusionofwork.wordpress.com/2016/03/01/artisan-od-a-new-tribe-for-the-hr-world/, $1^{\text {st }}$ March, 2016. Web. 